\title{
Variabilitas Pola Perdarahan Anak Hemofilia A yang Mendapat Terapi On- demand di Rumah Sakit Cipto Mangunkusumo
}

\author{
Novie Amelia Chozie, Yuniasti Evitasari, Darmawan Budi Setyanto \\ Departemen Ilmu Kesehatan Anak Fakultas Kedokteran Universitas Indonesia/RS. Cipto Mangunkusumo, Jakarta
}

\begin{abstract}
Latar belakang. Gejala perdarahan pada hemofilia A bergantung pada kadar faktor VIII, namun pada kadar faktor koagulasi yang sama dapat terjadi perbedaan karakteristik dan luaran klinis.

Tujuan. Mengidentifikasi pola perdarahan, terapi dan komplikasi pada anak hemofilia A.

Metode. Penelitian kohort retrospektif pada anak $\leq 18$ tahun di RSCM. Data diambil dari rekam medis (Januari 2014 - Juni 2016) meliputi data usia awitan perdarahan sendi, usia saat diagnosis, kekerapan perdarahan, lokasi perdarahan, penggunaan faktor VIII, dan komplikasi yang dialami.

Hasil. Terdapat 109 anak lelaki terdiri dari 2,8\% hemofilia A ringan, 27,5\% hemofilia A sedang, dan 69,7\% hemofilia A berat. Perdarahan tersering ditemukan pada sendi $(60,6 \%)$ terutama pada lutut (37,2\%). Dibandingkan hemofilia A ringan dan sedang, anak hemofilia A berat menunjukkan usia awitan perdarahan sendi lebih dini (median 12,5 (4-120) bulan), kekerapan perdarahan sendi lebih sering (median 8 (1-44) kali/tahun), dan menggunakan konsentrat faktor VIII lebih banyak (median 712 (131-1913) IU/ $\mathrm{kg} /$ tahun). Komplikasi terbanyak adalah artropati dan sinovitis kronik (46,8\%) serta inhibitor faktor VIII (7,3\%). Terdapat 9 dari $71(12,6) \%$ subjek hemofilia A berat menunjukkan karakteristik klinis lebih ringan.

Kesimpulan. Pola perdarahan pada anak hemofilia A sesuai kadar faktor VIII, tetapi pada hemofilia A berat terdapat variabilitas subjek dengan gejala klinis lebih ringan. Sari Pediatri 2018;20(4):221-9
\end{abstract}

Kata kunci: perdarahan, anak, komplikasi, hemofilia A

\section{Variability of Bleeding Pattern in Hemophilia A Children Receiving on Demand Treatment in Cipto Mangunkusumo Hospital}

Novie Amelia Chozie, Yuniasti Evitasari, Darmawan Budi Setyanto

Background. Bleeding phenotype in hemophilia A is related to factor VIII level and disease severity, but variability among severe hemophilia has been reported.

Objective. To identify clinical characteristics, factor VIII usage for on-demand therapy, and complications.

Method. A retrospective cohort study on children aged $\leq 18$ years was conducted in Hemophilia Comprehensive Treatment Center, Dr. Cipto Mangunkusumo Hospital. Data was obtained from medical record (January 2014 - June 2016) including age of diagnosis, age of first joint bleed, number of bleeding episodes, sites of bleeding, F VIII usage and complications.

Result. Total of 109 boys consisted of $2.8 \%$ mild, $27.5 \%$ moderate, and $69.7 \%$ severe hemophilia hemophilia A. The most common bleeding was hemarthrosis $(60.6 \%)$ of the knee (37.2\%). Severe hemophilia children showed earlier age of first joint bleed (median 12,5 (4-120) months), higher number of joint bleeds (median 8 (1-44)/year), and higher consumptions of clotting factor (median 712 (131 to 1913 ) IU/kg/year) compared to mild and moderate hemophilia. The most common complication in severe hemophilia were hemophilic arthropathy and chronic synovitis (46.8\%) and factor VIII inhibitors (7.3\%). We found 9 out of 71 (12.6\%) of severe hemophilia A patients showed milder bleeding phenotype.

Conclusion. clinical manifestation in hemophilia A children is in accordance with plasma level of factor VIII, however we found variability of severe hemophilia A patients with milder bleeding phenotype. Sari Pediatri 2018;20(4):221-9

Keywords: bleeding, children, complications, hemophilia A

Alamat korespondensi: Novie Amelia Chozie. Departemen Ilmu Kesehatan Anak FKUI-RSCM, Jl. Diponegoro 71, Jakarta 10430. E-mail : novie. amelia@ui.ac.id,novie37@gmail.com 
Novie Amelia Chozie dkk: Variabilitas pola perdarahan anak hemofilia A yang mendapat terapi on-demand

$\mathrm{H}$

emofilia A merupakan gangguan pembekuan darah yang disebabkan kekurangan faktor VIII dan diturunkan secara $X$-linked recessive. ${ }^{1}$ Menurut The Scientific and Standardization Committee of the International Society on Thrombosis and Haemostasis (ISTH), hemofilia A berat adalah bila kadar faktor VIII kurang dari $1 \%$, hemofilia A sedang bila kadarnya 1\%-5\%, dan hemofilia A ringan bila kadarnya lebih dari $5 \%-40 \% .^{2}$

Beberapa studi menunjukkan pasien hemofilia A berat memiliki karakteristik klinis yang jauh lebih ringan. ${ }^{3-7}$ Sekitar 10\%-15\% pasien hemofilia A berat tidak mengalami perdarahan sama sekali dan tidak mengalami artropati meskipun dengan terapi terbatas. ${ }^{3-5}$ Variasi tersebut dapat dilihat dari usia awitan perdarahan sendi, kekerapan perdarahan, penggunaan faktor pengganti, dan komplikasi yang dialami. ${ }^{5}$ Perdarahan sendi pada hemofilia A berat terjadi lebih awal dibandingkan hemofilia ringan dan sedang, yaitu pada usia kurang dari 1 tahun saat anak mulai aktif, namun dapat bervariasi antara usia 6 bulan hingga 6 tahun. ${ }^{6}$ Variabilitas klinis pada hemofilia sangat penting diketahui oleh klinisi sebagai dasar penentuan terapi dan pemberian faktor pembekuan. Tujuan penelitian ini adalah untuk mengetahui pola perdarahan, terapi dan luaran klinis pasien hemofilia A yang berobat di Pusat Pelayanan Terpadu Hemofilia Departemen Ilmu Kesehatan Anak RSUPN Dr. Cipto Mangunkusumo.

\section{Metode}

Studi kohort retrospektif dilakukan di Pusat Pelayanan Hemofilia Terpadu Departemen Ilmu Kesehatan Anak Rumah Sakit Dr. Cipto Mangunkusumo pada tahun 2016. Data diambil secara total sampling dari rekam medis (Januari 2014 - Juni 2016) meliputi usia awitan perdarahan sendi, usia saat didiagnosis, kekerapan perdarahan, lokasi perdarahan, penggunaan faktor VIII, dan komplikasi yang dialami. Kriteria inklusi adalah pasien hemofilia $\mathrm{A}$, berusia $\leq 18$ tahun saat pengambilan data (Juni 2016), dan memiliki data faktor VIII. Bila rekam medis pasien hilang atau tidak lengkap maka pasien dieksklusi dari penelitian. Semua data yang diperoleh dicatat dalam formulir laporan penelitian. Data disajikan secara tekstular dan tabular. Data dengan sebaran yang normal disajikan sebagai rerata $( \pm S D)$ sedangkan data yang memiliki sebaran yang tidak normal disajikan sebagai median (kisaran).

\section{Hasil}

Hasil penelusuran rekam medis dengan menggunakan kode berdasarkan International Classification of Disease (ICD) 10 untuk hemofilia A (D66) mendapatkan 110 kasus. Dari total 110 kasus tersebut, semua rekam medis berhasil ditemukan. Satu kasus dieksklusi karena rekam medis tidak lengkap. Seluruh subjek penelitian $(\mathrm{n}=109)$ berjenis kelamin laki-laki. Riwayat keluarga hemofilia didapatkan pada $51(46,8 \%)$ subjek (Tabel 1). Terdapat 95 subjek yang kontrol teratur ke RSCM dari 109 subjek yang memenuhi kriteria inklusi; tiga pindah ke RSUD Tangerang, tiga ke RSUP Fatmawati, dua ke RSUD Serang, dua ke RS Hasan Sadikin Bandung, satu ke RS Palang Merah Indonesia Bogor, dua subjek didiagnosis hemofilia dalam waktu kurang dari 1 tahun pada saat pengambilan data, dan 1 satu subjek tidak kontrol kembali dengan alasan yang tidak diketahui. Data kekerapan perdarahan, penggunaan faktor pengganti dan kekerapan kunjungan ke RS dianalisis dari 95 subjek yang kontrol teratur.

Subjek yang kontrol teratur ke RSCM terdiri dari $2(2,1 \%)$ subjek hemofilia A ringan, $22(22,9 \%)$ hemofilia A sedang, dan 71 (74,7\%) hemofilia A berat. Lokasi perdarahan yang paling sering ditemukan pada subjek penelitian adalah sendi $(60,6 \%)$ diikuti oleh otot $(31,3 \%)$. Sendi yang paling sering terlibat adalah sendi lutut $(37,2 \%)$, pergelangan kaki $(25,5 \%)$, dan siku $(24,4 \%)$.

Jenis terapi yang didapatkan oleh subjek penelitian 99,4\% adalah konsentrat faktor VIII. Terdapat 7 subjek hemofilia A berat yang menjalani tindakan pembedahan, yaitu sirkumsisi. Jumlah total kunjungan ke rumah sakit terdiri dari $98,4 \%$ rawat jalan dan $1,6 \%$ rawat inap. Alasan rawat inap $75 \%$ disebabkan oleh perdarahan dan $25 \%$ untuk tindakan sirkumsisi. Median lama rawat inap adalah 3 hari dengan kisaran 1-9 hari. Subjek hemofilia A ringan tidak ada yang menjalani rawat inap. Pada hemofilia A sedang terdapat 98,2\% kunjungan rawat jalan, dan 1,8\% rawat inap dengan median (kisaran) lama rawat inap 2 (1-5) hari. Pada hemofilia A berat terdapat 97,7\% kunjungan rawat jalan dan 2,3\% rawat inap dengan median (kisaran) lama rawat 3 (1-9) hari. Pada Tabel 2 disajikan data kekerapan perdarahan dan penggunaan konsentrat faktor VIII. 
Tabel 1. Karakteristik dasar subjek penelitian berdasarkan derajat hemofilia

\begin{tabular}{|c|c|c|c|}
\hline \multirow[t]{2}{*}{ Karakteristik } & \multicolumn{3}{|c|}{ Derajat hemofilia $(n=109)$} \\
\hline & $\begin{array}{c}\text { Ringan } \\
\mathrm{n}(\%)\end{array}$ & $\begin{array}{c}\text { Sedang } \\
\mathrm{n}(\%)\end{array}$ & $\begin{array}{l}\text { Berat } \\
\text { n (\%) }\end{array}$ \\
\hline Jumlah subjek & $3(2,8)$ & $30(27,5)$ & $76(69,7)$ \\
\hline Usia (tahun)* & $9((7-14)$ & $7(2-18)$ & $11(3-17)$ \\
\hline$<5$ & $0(0)$ & $11(36,7)$ & $3(3,9)$ \\
\hline $5-10$ & $2(66,7)$ & $10(33,3)$ & $32(42,2)$ \\
\hline$>10-18$ & $1(33,3)$ & $9(30)$ & $41(53,9)$ \\
\hline Usia saat didiagnosis* (tahun) & $30(15-60)$ & $24,5(8-180)$ & $27(1-134)$ \\
\hline$<2$ & $1(33,3)$ & $12(40)$ & $35(46,1)$ \\
\hline $2-5$ & $2(66,7)$ & $11(36,7)$ & $23(30,3)$ \\
\hline$>5$ & $0(0)$ & $7(23,3)$ & $18(23,7)$ \\
\hline Usia awitan perdarahan sendi* (tahun) & $28(12-60)$ & $18(7-120)$ & $12,5(4-120)$ \\
\hline Belum ada & $0(0)$ & $1(3,3)$ & $0(0)$ \\
\hline$<2$ & $2(66,7)$ & $15(50)$ & $45(59,2)$ \\
\hline $2-5$ & $0(0)$ & $8(26,7)$ & $22(28,9)$ \\
\hline$>5$ & $1(33,3)$ & $4(13,3)$ & $9(11,9)$ \\
\hline Tidak ada data & $0(0)$ & $2(6,7)$ & $0(0)$ \\
\hline \multicolumn{4}{|l|}{ Riwayat keluarga } \\
\hline Ada & $1(33,3)$ & $8(26,7)$ & $42(55,3)$ \\
\hline Tidak ada & $2(66,7)$ & $22(73,3)$ & $34(44,7)$ \\
\hline
\end{tabular}

*median (kisaran)

Tabel 2. Kekerapan perdarahan dan penggunaan konsentrat faktor VIII berdasarkan derajat hemofilia

\begin{tabular}{lccc}
\hline \multirow{2}{*}{ Karakteristik } & \multicolumn{3}{c}{ Derajat hemofilia [median (kisaran)] } \\
\cline { 2 - 4 } & Ringan $(\mathrm{n}=2)$ & Sedang $(\mathrm{n}=22)$ & Berat $(\mathrm{n}=71)$ \\
\hline Kekerapan perdarahan (kali/tahun) & $0(0-3)$ & $9,5(2-29)$ & $16(3-46)$ \\
Kekerapan perdarahan sendi (kali/tahun) & $1(0-2)$ & $4,5(0-24)$ & $8(1-44)$ \\
Penggunaan konsentrat faktor VIII (IU/kg/tahun) & $81(71-92)$ & $334(71-1554)$ & $726(131-2273)$ \\
$\begin{array}{l}\text { Penggunaan konsentrat faktor VIII di luar tindakan sirkumsisi } \\
\text { (IU/kg/tahun) }\end{array}$ & $81(71-92)$ & $334(71-1554)$ & $712(131-1913)$ \\
$\begin{array}{l}\text { Lama pemberian konsentrat faktor VIII per episode perdarahan } \\
\text { (hari) }\end{array}$ & $1,5(1,3-1,7)$ & $1,5(1,0-2,0)$ & $1,5(1,1-2,0)$ \\
\hline
\end{tabular}

Tabel 3. Komplikasi

\begin{tabular}{lcccc}
\hline \multirow{2}{*}{ Komplikasi } & $\mathrm{n}(\%)$ & \multicolumn{3}{c}{ Derajat hemofilia $(\mathrm{n}, \%)$} \\
\cline { 3 - 5 } & $(\mathrm{n}=109)$ & Ringan $(\mathrm{n}=3)$ & Sedang $(\mathrm{n}=30)$ & Berat $(\mathrm{n}=76)$ \\
\hline Artropati hemofilik* & $51(46,8)$ & $0(0)$ & $0(0)$ & $51(67,1)$ \\
Sinovitis kronis* & $51(46,8)$ & $0(0)$ & $1(3,3)$ & $50(65,8)$ \\
Pseudotumor & $1(0,9)$ & $0(0)$ & $0(0)$ & $1(1,3)$ \\
Fraktur & $1(0,9)$ & $0(0)$ & $0(0)$ & $1(1,3)$ \\
Anemia akibat perdarahan & $2(1,8)$ & $0(0)$ & $0(0)$ & $2(2,6)$ \\
Inhibitor FVIII & $8(7,3)$ & $0(0)$ & $1(3,3)$ & $7(9,2)$ \\
\hline
\end{tabular}

*berdasarkan pemeriksaan radiologis (USG+Rontgen) 
Tabel 4. Variabilitas karakteristik klinis subjek hemofilia A berat berdasarkan usia

\begin{tabular}{lcccccc}
\hline & \multicolumn{3}{c}{$\begin{array}{c}\text { Usia subjek } \\
\text { (tahun) }\end{array}$} & \multicolumn{5}{c}{ Usia awitan perdarahan sendi (tahun) } \\
\cline { 2 - 7 } Karakteristik & $<5$ & $5-10$ & $>10$ & $<2$ & $2-5$ & $>5$ \\
$(\mathrm{n}=2)$ & $(\mathrm{n}=30)$ & $(\mathrm{n}=39)$ & $(\mathrm{n}=2)$ & $(\mathrm{n}=30)$ & $\begin{array}{c}> \\
(\mathrm{n}=39)\end{array}$ \\
\hline Kekerapan perdarahan & 6,5 & 6,5 & 11 & 31,5 & 15 & 16 \\
[median (kisaran) kali/tahun] & $(6-7)$ & $(1-14)$ & $(1-44)$ & $(4-40)$ & $(6-36)$ & $(3-46)$ \\
Kekerapan perdarahan sendi & 5 & 15,5 & 20 & 19 & 7 & 8 \\
[median (kisaran) kali/tahun] & $(4-6)$ & $(3-35)$ & $(3-46)$ & $(4-37)$ & $(1-23)$ & $(1-44)$ \\
Penggunaan konsentrat faktor VIII diluar & 273 & $674( \pm 358)$ & 691 & $913( \pm 589)$ & $691( \pm 428)$ & 670 \\
tindakan sirkumsisi & $( \pm 90)$ & & $( \pm 449)$ & & & $( \pm 361)$ \\
[mean $( \pm$ SD) IU/kg/tahun] & & & & & & \\
\hline
\end{tabular}

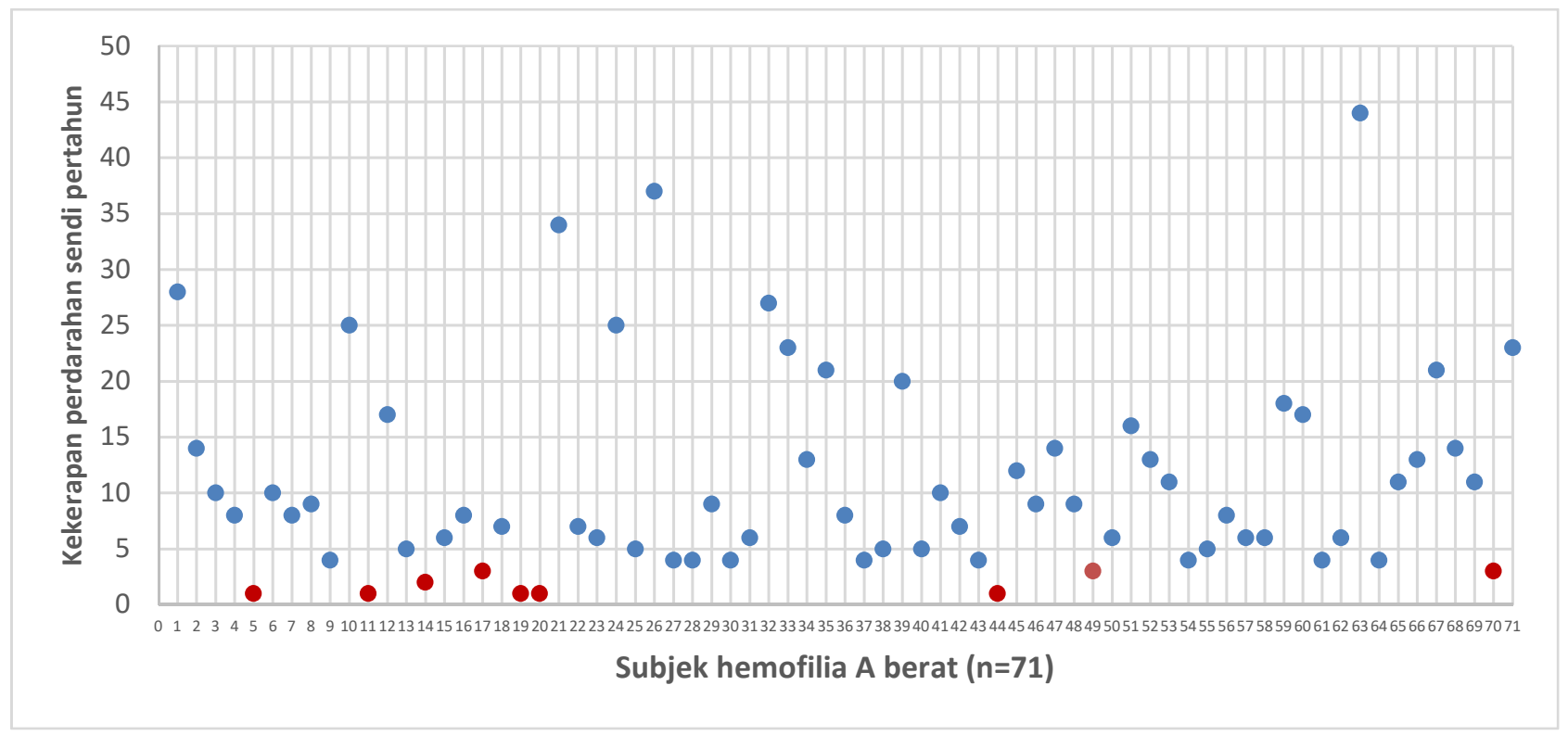

Gambar 1. Kekerapan perdarahan sendi per tahun pada subjek hemofilia A berat $(\mathrm{n}=71)$

Artropati hemofilik dan sinovitis merupakan komplikasi yang paling banyak ditemukan yaitu sebanyak 51 (46,8\%) subjek (Tabel 3). Pada hemofilia A ringan tidak didapatkan komplikasi. Artropati, pseudotumor, fraktur, dan anemia akibat perdarahan hanya ditemukan pada subjek hemofilia A berat. Menurut usia subjek penelitian, komplikasi ditemukan pada usia lebih dari 5 tahun. Usia paling muda yang mengalami artropati adalah 6 tahun.

Terdapat 51 subjek yang mengalami artropati, seluruhnya diketahui berdasarkan pemeriksaan USG, $50(92,5 \%)$ subjek dilakukan pemeriksaan HJHS, dan 26 (51\%) subjek dilakukan pemeriksaan X-Ray. Tidak didapatkan data pemeriksaan klinis dan radiologis pada 44 subjek lainnya. Dari 51 subjek yang mengalami sinovitis kronis, 50 (98\%) didiagnosis berdasarkan pemeriksaan USG dan 1 (2\%) subjek berdasarkan X-Ray. Satu subjek didiagnosis pseudotumor berdasarkan temuan klinis dan 1 subjek didiagnosis fraktur berdasarkan hasil X-Ray. Tidak ada subjek yang memiliki data pemeriksaan CT scan dan MRI.

Variabilitas karakteristik klinis dan kebutuhan faktor VIII berdasarkan usia dan usia awitan perdarahan sendi tertera pada Tabel 4 . Terdapat $9(12,6 \%)$ dari 71 subjek hemofilia A berat menunjukkan karakteristik klinis lebih ringan, yaitu perdarahan sendi hanya 1-3 
kali pertahun (Gambar 1). Sembilan subjek hemofilia A berat tersebut memiliki median usia awitan perdarahan sendi 17,6 (5-54) bulan dan median usia saat diagnosis 32,3 (5-101) bulan,

\section{Pembahasan}

Proporsi pasien hemofilia berdasarkan kadar plasma faktor VIII bervariasi di beberapa negara. The National Hemophilia Registry of China menunjukkan kasus hemofilia A ringan 16\% dari 5043 kasus, Italian Hemophilia Registry menunjukkan 34\% dari 2679 kasus, Canadian Hemophilia Registry menunjukkan 51\% dari 1594 kasus, dan Geraghty dkk ${ }^{9}$ melaporkan $32 \%$ dari 16.115 kasus. Pada penelitian kami proporsi hemofilia A ringan lebih kecil, yaitu sebesar 2,8\%, sedangkan hemofilia A berat $69,7 \%$ dan hemofilia A sedang 27,5\%, dan 2,8\% hemofilia A ringan. Perbedaan proporsi tersebut berkaitan dengan pendekatan diagnosis, tingginya kewaspadaan tenaga medis, serta investigasi berdasarkan riwayat keluarga. ${ }^{8-11}$ Pada hemofilia A ringan jarang terjadi perdarahan spontan sehingga orangtua jarang membawa anaknya ke fasilitas kesehatan. Pasien hemofilia A ringan seringkali didiagnosis karena adanya perdarahan akibat trauma/ ekstraksi gigi, perdarahan intra/pasca-operasi, riwayat keluarga positif, atau secara kebetulan melalui skrining laboratorium sebelum operasi. ${ }^{12,13}$

Beberapa studi melaporkan median usia saat diagnosis hemofilia pada usia 6 bulan hingga 1 tahun. ${ }^{14-16}$ Pada studi kohort di Perancis dengan jumlah subjek 599 orang, median usia saat didiagnosis hemofilia A ringan adalah 28,6 bulan, lebih lama dibandingkan hemofilia sedang, yaitu 9 bulan, dan hemofilia A berat yaitu 5,8 bulan. ${ }^{17}$ Penelitian kami menunjukkan median usia diagnosis pada subjek hemofilia A berat tidak jauh berbeda dengan dengan hemofilia A sedang dan ringan, hal ini kemungkinan disebabkan oleh keterlambatan diagnosis terutama pada hemofilia A berat dibandingkan dengan di negara maju, baik karena terbatasnya fasilitas dan sarana diagnostik, biaya, maupun ketidaktahuan orang tua.

Pasien hemofilia A berat mulai mengalami perdarahan lebih awal yaitu pada usia 6-8 bulan atau pada saat anak mulai aktif. ${ }^{4,5}$ Ghany $\mathrm{dkk}^{18}$ melaporkan median (kisaran) usia awitan perdarahan sendi pada hemofilia A ringan 4,5 (2,0-5,0) tahun, hemofilia A sedang 5 (3-5) tahun, dan hemofilia A berat 2,0
$(0,5-4,0)$ tahun. Hang $\mathrm{dkk}^{19}$ menunjukkan awitan perdarahan sendi pada anak hemofilia A berat adalah 1,7 tahun dengan kisaran 1,0-2,8 tahun, serupa dengan studi oleh Van Dijk ${ }^{6}$ yaitu 1,8 tahun dengan kisaran 1,1-2,7 tahun. Penelitian kami juga mendapatkan median usia awitan perdarahan sendi termuda adalah subjek hemofilia A berat, berikutnya adalah subjek hemofilia A sedang dan median usia subjek hemofilia A ringan merupakan yang tertua.

Usia awitan perdarahan sendi merupakan indikator penting dalam menilai pola perdarahan pada pasien hemofilia A berat. ${ }^{6}$ Penelitian kami menunjukkan median (kisaran) usia awitan perdarahan sendi pada subjek hemofilia A berat adalah 12,5 (4-120) bulan. Subjek yang mengalami perdarahan sendi kurang dari 2 tahun memiliki kekerapan perdarahan yang lebih sering serta penggunaan konsentrat yang lebih banyak. Median (kisaran) usia awitan perdarahan sendi pada subjek yang mengalami artropati juga lebih muda yaitu 12 (6-72) bulan dibandingkan subjek yang tidak mengalami artropati yaitu 14,5 (4-120) bulan. Hal ini sesuai dengan studi oleh Van Dijk dkk yang menunjukkan bahwa subjek dengan usia awitan perdarahan sendi yang lebih awal berkaitan dengan penggunaan konsentrat faktor VIII yang lebih tinggi dibandingkan dengan subjek dengan usia awitan perdarahan sendi yang lebih lambat dan terdapat korelasi positif antara penggunaan konsentrat faktor VIII dan frekuensi perdarahan sendi.

Penelitian kami menunjukkan kekerapan perdarahan total dan perdarahan sendi pada subjek hemofilia A berat lebih sering dibandingkan hemofilia A sedang, dan yang paling jarang adalah pada hemofilia A ringan. Studi oleh Den Uijl $\mathrm{dkk}^{2}$ menunjukkan pada hemofilia A ringan median (kisaran) kekerapan perdarahan 0 (03) kali/tahun dan perdarahan sendi $0(0-0) \mathrm{kali} / \mathrm{tahun}$; hemofilia A sedang 1 (0-13) kali/tahun dan 0 (0-6) kali/ tahun; serta hemofilia A berat $6(0-25) \mathrm{kali} / \mathrm{tahun}$ dan 3 (0-15) kali/tahun. Pada pasien hemofilia yang tidak mendapat terapi profilaksis, hal ini merupakan implikasi dari kadar plasma faktor VIII sesuai derajat penyakit. Kekerapan perdarahan dan penggunaan konsentrat faktor VIII berbanding lurus dengan usia subjek. Subjek yang berusia lebih dari 10 tahun mengalami kekerapan perdarahan yang lebih sering baik pada sendi maupun non-sendi, dan penggunaan konsentrat faktor VIII lebih banyak. Hal ini dapat berkaitan dengan pola aktivitas fisik, tingkat kemandirian, serta unsur protektif dari orangtua. ${ }^{34}$ 
Lokasi perdarahan yang paling banyak ditemukan pada subjek penelitian ini adalah sendi diikuti oleh otot. Sendi yang paling sering terlibat adalah sendi lutut, pergelangan kaki, dan siku. Sesuai dengan data dari WFH, jenis perdarahan yang paling banyak ditemukan pada pasien hemofilia adalah perdarahan pada sendi $(70-80) \%$, dan otot (10-20)\%. ${ }^{20,21}$ Lutut dan pergelangan kaki memiliki fungsi sebagai penopang berat badan sehingga potensi terjadinya perdarahan di lokasi tersebut lebih tinggi. Data dari Universal Data Collection menunjukkan bahwa pasien hemofilia A berat memiliki risiko perdarahan sendi yang lebih tinggi dibandingkan hemofilia A sedang dan ringan (33,1\% vs $18,8 \%$ dan $5 \%) .{ }^{21}$

Hasil penelitian kami menunjukkan median (kisaran) penggunaan konsentrat faktor VIII terbanyak pada subjek hemofilia A berat, sesuai dengan kekerapan perdarahan yang lebih banyak terjadi dibandingkan dengan subjek hemofilia A sedang dan ringan. Walaupun sama-sama menggunakan pola terapi ondemand, jumlah ini lebih sedikit dibandingkan dengan studi oleh Ekert dkk, ${ }^{22}$ yaitu $1350 \mathrm{IU} / \mathrm{kg} /$ tahun, studi oleh Aledort dkk ${ }^{23} 1038 \mathrm{IU} / \mathrm{kg} /$ tahun, serta studi oleh Smith $\mathrm{dkk}^{24} 1015 \mathrm{IU} / \mathrm{kg} /$ tahun. Hal ini disebabkan oleh dosis terapi on-demand yang digunakan di RSCM relatif lebih rendah, yakni mengacu pada panduan World Federation of Haemophilia untuk negara dengan keterbatasan.

Pemantauan komplikasi muskuloskeletal secara klinis dapat menggunakan metode Hemofilia Joint Health Score yang dikembangkan oleh International Prophylaxis Study Group yang cukup sensitif mendeteksi kerusakan sendi tahap dini. ${ }^{27}$ Penilaian secara radiologis dilakukan dengan pemeriksaan X-Ray sendi, USG maupun MRI. ${ }^{25,26}$ Artropati hemofilik dan sinovitis kronik pada penelitian ini sebesar 46,8\%. Median (kisaran) usia pada subjek yang mengalami artropati adalah $12(6-17)$ tahun. Data diperoleh dari 51 subjek hemofilia A berat yang menjalani pemeriksaan radiologis (X-Ray dan USG) dan HJHS. Mengingat pola terapi on-demand yang diterapkan sampai saat ini, kemungkinan besar prevalens artropati dan synovitis kronis pada pasien kami lebih besar lagi dan diperlukan penelitian lebih lanjut mengenai hal ini.

Prevalens inhibitor faktor VIII pada hemofilia A bervariasi antara 3,6-52\% dengan prevalens terbesar pada ras Afrika-Amerika, Kaukasian, dan Latin. ${ }^{28,23}$
Pada ras Asia, prevalensnya jauh lebih rendah yaitu 1,4-10,4\%. ${ }^{29-32}$ Pada penelitian ini, prevalens inhibitor faktor VIII adalah 7,3\% dan $87,5 \%$ diantaranya ditemukan pada hemofilia A berat. Selain faktor ras, pola terapi on demand, dosis terapi yang relatif rendah dan konsentrat faktor VIII yang berasal dari plasma (plasma derived clotting factor concentrate) merupakan faktor-faktor yang dapat berkontribusi terhadap rendahnya prevalens inhibitor pada subjek penelitian kami.

Pseudotumor merupakan komplikasi yang jarang ditemukan pada pasien hemofilia dengan prevalens sekitar $1 \%{ }^{33}$ Pada penelitian ini didapatkan hasil $1,1 \%$. Pada penelitian ini tidak didapatkan subjek yang memiliki data-data pemeriksaan infeksi HIV, hepatitis $\mathrm{B}$, maupun hepatitis $\mathrm{C}$ karena pemeriksaan tersebut tidak rutin dilakukan.

Banyak studi melaporkan bahwa kadar faktor VIII dalam sirkulasi tidak selalu dapat menjadi prediktor berat-ringannya manifestasi klinis. Perbedaan jenis mutasi gen faktor VIII bukan merupakan penentu utama variabilitas fenotip pasien hemofilia A berat. ${ }^{34}$ Variasi pola perdarahan pasien hemofilia A berat akan memengaruhi strategi terapi yang akan diberikan. Meskipun profilaksis primer untuk mencegah terjadinya perdarahan merupakan pilihan utama pada anak hemofilia A berat, anak dengan karakteristik klinis yang ringan dapat memulai terapi profilaksis lebih lambat atau dengan dosis kecil sehingga meningkatkan efektivitas biaya terapi. ${ }^{35}$ Sebaliknya, pasien hemofilia A berat dengan karakteristik klinis yang berat mendapat terapi profilaksis sedini mungkin untuk mencegah kekerapan perdarahan dan terjadinya artropati hemofilik. ${ }^{36} \mathrm{Hal}$ ini penting untuk diketahui sebelum terapi profilaksis dimulai, terutama mengingat mahalnya biaya profilaksis. Pada penelitian kami terdapat 9 subjek $(12,6 \%)$ subjek hemofilia A berat dengan kekerapan perdarahan sendi hanya 1-3 kali pertahun, dan memiliki usia awitan perdarahan sendi lebih tua dibandingkan dengan median usia awitan perdarahan sendi kelompok subjek hemofilia A berat secara keseluruhan. Demikian pula usia saat didiagnosis hemofilia pada ke-9 subjek tersebut lebih tua dibandingkan kelompok subjek hemofilia A ringan. Faktor-faktor yang diduga dapat menyebabkan variasi manifestasi klinis pada hemofilia berat adalah perbedaan aktivitas fibrinolisis, ${ }^{37-39}$ variasi platelet coagulation activity, ${ }^{40}$ adanya co-inheritance mutasi gen protrombotik (mutasi pada gen 5,10 - 
methylenetetrahydropholate reductase (MTHFR), ${ }^{40-42}$ substitusi G1691A gen faktor V (Faktor V Leiden) ${ }^{39,43}$ dan mutasi G20210A ${ }^{44}$ pada gen protrombin), yang mengubah keseimbangan hemostasis dalam keadaan defisiensi faktor VIII. Van Dijk dkk ${ }^{35}$ melaporkan bahwa pasien hemofilia yang memiliki faktor protrombotik mengalami perdarahan pertama kali pada usia yang lebih tua yaitu 1,6 tahun, berbeda bermakna dibandingkan dengan yang tidak memiliki faktor protrombotik. Selain itu, faktor lingkungan juga berperan penting, seperti bervariasinya aktivitas fisik dan kebugaran fisik/muskuloskeletal masingmasing. ${ }^{45}$

Penelitian kami memiliki keterbatasan terkait data rekam medis yang diambil secara retrospektif, sehingga ada kemungkinan perdarahan sendi yang diobati sendiri di rumah tidak tercatat. Tidak semua subjek memiliki data pemeriksaan muskuloskeletal (HJHS) dan pemeriksaan radiologis sehingga kemungkinan jumlah pasien yang mengalami artropati dan sinovitis kronik lebih kecil dari yang seharusnya. Perlu dilakukan studi prospektif untuk mengatasi keterbatasan ini.

\section{Kesimpulan}

Subjek hemofilia A berat menunjukkan usia awitan perdarahan sendi lebih dini, kekerapan perdarahan sendi dan non sendi lebih tinggi, membutuhkan konsentrat faktor VIII lebih banyak dan mengalami komplikasi artropati dan sinovitis kronik lebih sering dibandingkan subjek hemofilia A ringan dan sedang. Terdapat $12,6 \%$ subjek hemofilia A berat memiliki karakteristik klinis yang lebih ringan. Hal ini perlu dipertimbangkan dalam penentuan terapi faktor VIII secara individual, khususnya untuk profilaksis.

\section{Daftar pustaka}

1. Acharya SS. Hemostatic disorders. Dalam: Lanskowsky P, penyunting. Manual of pediatric hematology and oncology. Edisi ke-5. New York: Elsevier; 2011.h.396-409.

2. Den Uijl IEM, Fischer K, Van Der bom JG, Grobbee DE, Rosendal FR, Plug I. Clinical outcome of moderate haemophilia compared with severe and mild haemophilia. Haemophilia 2009;15:83-90.
3. Ettingshausen CE, Halimeh S, Kurnik K, Schobess R, Wermes C, Junker R, dkk. Symptomatic onset of severe hemofilia A in childhood is dependent on the presence of prothrombotic risk factors. Thomb Haemost 2001;85:218-20.

4. Bolton-Maggs PH, Pasi KJ. Haemophilias A and B. Review. Lancet 2003;361:1801-9.

5. Onwuzurike N, Warrier I, Lusher JM. Types of bleeding seen during the first 30 month of life in children with severe haemophilia A and B. Haemophilia 1996;2:137-140.

6. Van Djik K, Van der Bom JG, Fischer K, Grobbee DE, Van der berg HM. Variability in clinical phenotype of severe haemophilia; the role of first joint bleed. Haemophilia 2005;11:438-43.

7. Van der Berg HM, Fischer K. Phenotypic-genotypic relationship. Dalam: Lee C, Berntop E, Hoots K, penyunting. Textbook of hemofilia. Edisi ke-2. Oxford; 2010.h.33-7.

8. Poon MC, Luke KH. Haemophilia care in China: achievements of a decade of World Federation of Hemofilia treatment centre twinning activities. Haemophilia 2008;14:87988.

9. Geraghty S, Dunkley T, Harrington C, Lindvall K, Maahs J, Sek J. Practice patterns in haemophilia A therapy-global progress towards optimal care. Haemophilia 2006;12:7581.

10. Iorio A, Oliovecchio E, Morfini M, Mannucci PM, Association of Italian Hemofilia Centres Directors, Italian Registry of Haemophilia and Allied Disorders. Objectives, methodology and data analysis. Haemophilia 2008; 14:444-53.

11. Walker I, Pai M, Akabutu J, Ritchie B, Growe G, PoonMC, dkk. The Canadian Hemofilia Registry as the basis for a national system for monitoring the use of factor concentrates. Transfusion 1995;35:548-51.

12. Franchini M, Favaloro EJ, Lippi G. Mild hemofilia A. J Thromb Haemost 2010;8:421-32.

13. Scott JP, Montgomery RR. Hereditary clotting factor. Dalam: Kliegman RM, Behrman RE, Jenson HB, Stanton BF, penyunting. Nelson textbook of pediatrics. Edisi ke-18. Philadelphia: WB Saunders Co; 2007. h.2066-74.

14. Fischer K, van der Bom JG, Molho P, Negrier C, MauserBunschoten EP, Roosendaal G, dkk. Prophylactic versus on-demand treatment strategies for severe haemophilia: a comparison of costs and long-term outcome. Haemophilia 2002;8:745-52.

15. Gringeri A, Lundin B, von Mackensen S, Mantovani L, Mannucci PM. A randomized clinical trial of prophylaxis in children with hemofilia A. J Thromb Haemost 2011;9:700-10.

16. Carlsson KS, Hojgard S, Glomstein A, Lethagen S, Schulman $\mathrm{S}$, Tengborn L, dkk. On-demand vs prophylactic treatment for severe haemophilia in Norway and Sweden: differences 
in treatment characteristics and outcome. Haemophilia 2003;9:555-66.

17. Chambost H, Gaboulaud V, Coatme'lec B, Rafowicz A, Schneider P, Calvez T, dkk. What factors influence the age at diagnosis of hemofilia? Results of the French hemofilia cohort. J Pediatr 2002;141:548-52.

18. Ghany HMA, Hassab HMA, Noueam KIE. Hemophilic arthropathy: clinical, radiologic, and functional evaluation: a single-center experience in a limited resource country. Egypt Rheumatol Rehabil 2016;43:35-40.

19. Hang MX, Blanchette VS, Pullenayegum E, McLimont M, Feldman BM. Age at first joint bleed and bleeding severity in boys with severe hemofilia A: Canadian Hemofilia Primary Prophylaxis Study. J Thromb Haemost 2011;9:1067-9.

20. World Federation of Hemofilia. Diagnosis and management of inhibitors to factor VIII and IX: an introductory discussion for physicians. California: The World Federation of Hemofilia; 2004. h.1-22.

21. Sorensen B, Ingerslev J. Whole Blood clot formation phenotypes in hemofilia $\mathrm{A}$ and rare coagulation disorders. Patterns of response to recombinant factor VIIa. J Thromb Haemost 2004;2:102-10.

22. Ekert H, Ekert NL, Street AM, Rickard KA, McPherson VJ, Toogood IR, dkk. Haemophilia A management in Victorian, New South Wales and South Australian haemophilia centres. Med J Aust 1995;162:569-71.

23. Aledort LM, DiMichele DM. Inhibitors occur more frequently in African-American and Latinohemofiliacs. Hemofilia 1998;4:68-73.

24. Smith PS, Teutsch SM, Shaffer PA, Rolka H, Evatt B. Episodic versus prophylactic infusions for haemophilia A: a cost effectiveness analysis. J Pediatr 1996;129:424-31.

25. Cross S, Vaidya S, Fotiadis N. Hemophilic arthropathy: a review of imaging and staging. Semin Ultrasound CT MRI 2013;34:516-24.

26. Muca-Perja M, Riva S, Grochowska B, Mangiafico L, Mago D, Gringeri A. Ultrasonography of haemophilic arthropathy. Haemophilia 2012;18:364-8.

27. Hilliard P, Funk S, Zourikian N, Bergstrom BM, Bradley CS, McLimont M, dkk. Hemofilia Joint Health Score reliability study. Haemophilia 2006;12:518-25.

28. Addiego J, Kasper C, Abildgaard C. Increased frequency of inhibitors in African American hemofilia A patients. Blood 1994;84:239-49.

29. Chen YC, Hu SH, Cheng SN, Chao TY. Genetic analysis of haemophilia A in Taiwan. Hemofilia 2010;16:538-44.

30. Xue F, Zhang L, Sui T. Factor VIII gene mutations profile in 148 Chinese hemofilia A subjects. Eur J Hematol 2010;85:264-72.

31. Owaidah TM, Alkhail HA, Zahrani HA, Al Musa A, Al Saleh
M, Riash MA, dkk. Molecular genotyping of hemofilia A in Saudi Arabia: report of two novel mutations. Blood Coagul Fibrinolysis 2009;20:415-8.

32. Awidi A, Ramahi M, Alhattab D, Mefleh R, Dweiri M, Bsoul N, dkk. Study of mutations in Jordanian patients with hemofilia A: identification of five novel mutations. Haemophilia 2010;16:136-42.

33. Heim M, Martinowitz U. Pseudotumors in patients with hemofilia. Dalam: Lee C, Berntop E, Hoots K, penyunting. Textbook of hemofilia. Edisi ke-2. Oxford; 2010. h. 18790.

34. Carcao MD, van den Berg HM, Ljung R, Mancuso ME. Correlation between phenotype and genotype in a large unselected cohort of children with severe hemofilia A. Blood 2013;121:3946-52.

35. Van Dijk K, van der Bom JG, Lenting PJ, de Groot PG, Bunschoten EPM, Rosendaal G, dkk. Factor VIII half-life and clinical phenotype of severe hemofilia A. Haematologica 2005;90:494-8.

36. Van Dijk K, van der Bom JG, Fischer K, Grobbee DE, van den Berg HM. Do prothrombotic factors influence clinical phenotype of severe haemophilia? A review of the literature. Thromb Haemost 2004;92:305-10.

37. Grunewald A, Siegemund A, Grunewald M, Konegan A, Koksch M, Griesshammer M, dkk. Paradoxysmal hyperfibrinolysis is associated with a more intensely haemorrhagic phenotype in severe congenital haemophilia. Haemophilia 2002;8:768-5.

38. Lisman T, Mosnier LO, Lambert T, Mauser-Bunschoten EP,Meijers JCM, Nieuwenhuis HK, dkk. Inhibition of fibrinolysis by recombinant factor VIIa in plasma form patients with severe hemofilia A. Blood 2002;99:175-9.

39. Van dijk K, Van der Bom JG, Fischer K, De Groot PG, van den Berg HM. Phenotype of severe hemofilia A and plasma levels of risk factors for thrombosis. J Thromb Haemost 2007;5:1062-4.

40. Kunicki TJ, Orchekowski R, Annis PYH. Variability of integrin alpha 2 beta 1 activity on human platelets Blood 1993;82:2693-703.

41. Hamdy MSE, Nasr AS, Makhlouf MM, El-Saadany ZA, Samir M, DS M. Impact of prothrombotic risk factors in a cohort of Egyptian hemofilia A patients. Molecular Diagnosis and Therapy 2016;20:15-9.

42. Nowak-Gottl U, Escuriola C, Kurnik K, Schobess R, Horneff $\mathrm{S}$, Kosch A, dkk. What do we learn about combined inheritance of both genetic variations? Hamostaseologie 2003;23:3640.

43. Nichols WC, Amano K, Cacheris PM, Figueiredo MS, Michaelides K, Schwaab R, dkkl. Moderation of hemofilia 
A phenotype by the factor VR506Q mutation. Blood 1996;88:1183-7.

44. Tizzano EF, Soria JM, Coll I, Guzman B, Cornet M, Altisent C, dkk. The prothrombin 20210A allele influences clinical manifestations of haemophilia $\mathrm{A}$ in patients with intron 22 inversion and without inhibitors. Haematologica 2002;87:279-85.

45. Harris S, LN B. Exercise may decrease further destruction in the adult haemophilic joint. Haemophilia 2006;12:23740. 